Arq. Bras. Med. Vet. Zootec., v.65, n.3, p.705-709, 2013

\title{
Swimmer syndrome affecting an entire litter of kittens
}

\author{
[Síndrome do filhote nadador em ninhada completa de felinos] \\ D.J. Cardilli ${ }^{1}$, C.F. João ${ }^{2}$, F.A. Voorwald ${ }^{1}$, J.L.M. Faria ${ }^{3}$, M. Tinucci-Costa ${ }^{1}$, G.H. Toniollo ${ }^{1}$ \\ ${ }^{1}$ Unesp - Jaboticabal, SP \\ ${ }^{2}$ Universidade Federal do Pará - Castanhal, PA \\ ${ }^{3}$ Universidade de Uberaba - Uberaba, MG
}

\begin{abstract}
Swimmer syndrome is a developmental abnormality characterized by a delay in the ability to walk and move about and is manifested in newborns between 15 and 20 days of age. These animals exhibit constant coxofemoral articulation abduction, and their pelvic limbs move caudally and laterally. This case reports a litter of three crossbreeds kittens (26 days old) with swimmer syndrome. Each animal was treated with physical therapy and shackle bandages that kept their pelvic limbs bent and close to the body. After seven days, all of the animals exhibited normal ambulation, indicating that this treatment had a curative effect on the kittens.
\end{abstract}

Keywords: cat, swimmer, congenital abnormalities

\section{RESUMO}

A sindrome do filhote nadador é uma anormalidade do desenvolvimento caracterizada pelo atraso na capacidade de marcha e deslocamento, a qual se manifesta por volta dos 15 a 20 dias de idade. Os animais apresentam a articulação coxofemoral em constante abdução, deslocando os membros pélvicos lateral $e$ caudalmente. Este trabalho relata uma ninhada de três filhotes felinos, sem raça definida, de 26 dias de idade, acometidos por síndrome do filhote nadador, e discute possíveis causas, complicações e tratamentos. Os filhotes foram submetidos à fisioterapia, algemas e bandagens, as quais mantiveram os membros pélvicos flexionados junto ao corpo. Ao final de sete dias, todos os filhotes apresentavam deambulação normal, e o tratamento proposto pode ser considerado curativo para felinos.

Palavras-chave: gato, filhote nadador, anomalias congênitas

\section{INTRODUCTION}

Swimmer syndrome is an uncommon developmental disorder of the motor function, still poorly characterized, seen in dogs and less frequently in cats, at an average age of 15 to 21 days after birth (Dumon, 2005; Verhoeven et al., 2006). It is responsible for delayed physical movement capacity (Fossum, 2007), witch mainly affects the pelvic limbs, but occasionally also the thoracic limbs (Dumon, 2005; Verhoeven et al., 2006). The patients exhibit constant abduction due to bilateral hyperflexion of coxofemoral articulations, hyperextension of tibialpatellofemoral and tibiotarsal joints, and, when the thoracic limbs are affected, the newborns present inability to support the appendicular skeleton, leading to dorsoventral compression of the thorax, abdomen and pelvis, lateral cycling behavior, and caudolateral limb deflection, witch characterize a

Recebido em 16 de novembro de 2011

Aceito em 29 de novembro de 2012

E-mail: djcardilli@yahoo.com.br swimming-like movement (Dumon, 2005; Verhoeven et al., 2006; Yardimci et al., 2009; Linde-Forsberg, 2010; Ludwing et al., 2010). The persistent inability to ambulate effectively leads to flat thorax, skin lesions, milk regurgitation, cyanosis, dyspnea, and aspiration pneumonia (Dumon, 2005).

The etiology of swimmer syndrome is uncertain and difficult to prove. Many hypotheses have been suggested, including hereditary factors, environmental causes, unbalanced diet (excessive protein in the queen's diet), maternal metabolic disorders, musculoskeletal development problems, obesity, and neurological disorders (inadequate or delayed myelination of peripheral motor neurons or functional alterations in neuromuscular synapses) (Hosgood and Hoskins, 1998; Hoskins, 2001; Dumon, 2005; Verhoeven et al., 2006; Burger et al., 2007; Fossum, 2007; Yardimci et al., 2009; Linde-Forsberg, 2010). 
Malformations and deformities may occur simultaneously with this syndrome, such as thoracic dorsal deviation, dorsoventral compression and sternal deformation (pectus excavatum or flat chest syndrome), medial patellar luxation and malformation of articulations of the long bones (genu recurvatum) and innocent systolic murmur (Fossum et al., 1989; Hosgood and Hoskins, 1998; Hoskins, 2001; Fossum, 2007; Rahal et al., 2008; LindeForsberg, 2010).

In dogs, a predisposition for swimmer syndrome is higher in chondrodystrophic or brachycephalic breeds and, in cats, two cases have been described, a Devon Rex and a crossbreed cat (Fossum et al., 1985; Fossum et al., 1989; Verhoeven et al., 2006).

Normal puppies and kittens are able to stand and walk 10 to 15 days after birth, therefore, clinical signs may be seen as early as the first week of age (Hosgood and Hoskins, 1998; Hoskins, 2001; Yardimci et al., 2009). A definitive diagnosis can be made based on history, clinical signs and radiographic examination (Dumon, 2005; Verhoeven et al., 2006; Burger et al., 2007; Fossum, 2007; Yardimci et al., 2009; Linde-Forsberg, 2010).

A specific treatment protocol has not been documented in any literature, but animals affected by swimmer syndrome with or without complications, should be treated soon after diagnosis. This paper aims to describe the clinical aspects and functional rehabilitation of a successful conservative therapy for swimmer syndrome, which usually affects only one animal in a litter.

\section{CASE REPORTS}

Three crossbreed kittens from the same litter, two males and one female, 26 days old, with a history of ambulation difficulties and sternal recumbency were studied. Upon physical examination, all of the kittens appeared to be healthy, but their pelvic and thoracic limbs were extended and diverted laterally (Figure 1). They moved by dragging their limbs, in a movement similar to swimming. All of the kittens exhibited slight thoracic flattening, but no dyspnea or evidence of gene recurvatum. Neurological examination was considered normal. The kittens weighed $320 \pm 50$ grams, were only fed with breast milk, and lived on blankets in a brick cattery. The queen was a primiparous 3-year-old female fed with commercial food.

Thoracic radiography revealed slight thoracic flattening in all kittens, normal bone density, no cardiac or pulmonary involvement, no evidence of pectus excavatum, no sternum abnormality, no signs of osteopetrosis described in affected Dachshunds (Riser and Frankhauser, 1970), and no patellar luxation (Yardimci et al., 2009). No congenital abnormalities of cardiac and pulmonary vasculature were found upon echocardiography, and urinary incontinence was not observed in the female patient, different from the other previously reported cases (Yardimci et al., 2009).

For treatment, each animal received sling bandages, as shackles, and bandages on the pelvic limbs, which were kept bent and close to the body (Figure 2). This configuration was maintained for seven days. We didn't use the same treatment in the thoracic limbs to avoid excessive movement restriction. Bandaging started from the toes to the tarsal region, spiraling from lateral to medial over the dorsal aspect of the limb to obtain internal rotation of the paws, as recommended by Verhoeven et al. (2006). Care was taken to prevent ischaemia, oedema or dermatitis, and the bandages were changed every 24 hours. Before bandages were applied, the animals received physical therapy and thermotherapy that aimed to correct the anatomical deformities and strengthen the muscles. Passive flexion, extension and adduction of the tibial-patellofemoral, tibiotarsal and coxofemoral joints were performed for 15 minutes, associated with massage of the cranial tibial, quadriceps and biceps femoris muscles, as recommended by Verhoeven et al. (2006). The kittens were held on a rubber based table in a normal standing position, with the pelvic limbs in adduction while gradually releasing manual support, to promote walking, muscle support and strength. Warm water compresses were applied on the limbs to stimulate arterial hyperaemia, which increases oxygen delivery to tissues and metabolic activity of muscles, as recommended by Millis and Levine (1997) and Clark and McLaughlin (2001). 


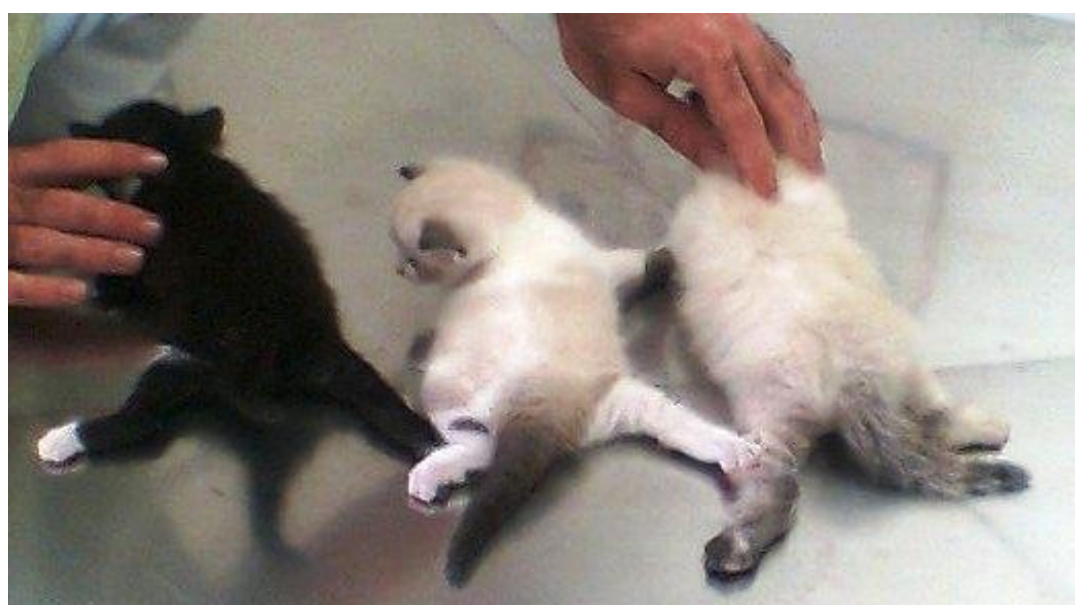

Figure. 1. A litter of three kittens with swimmer syndrome (showing the pelvic and thoracic limbs diverted laterally).

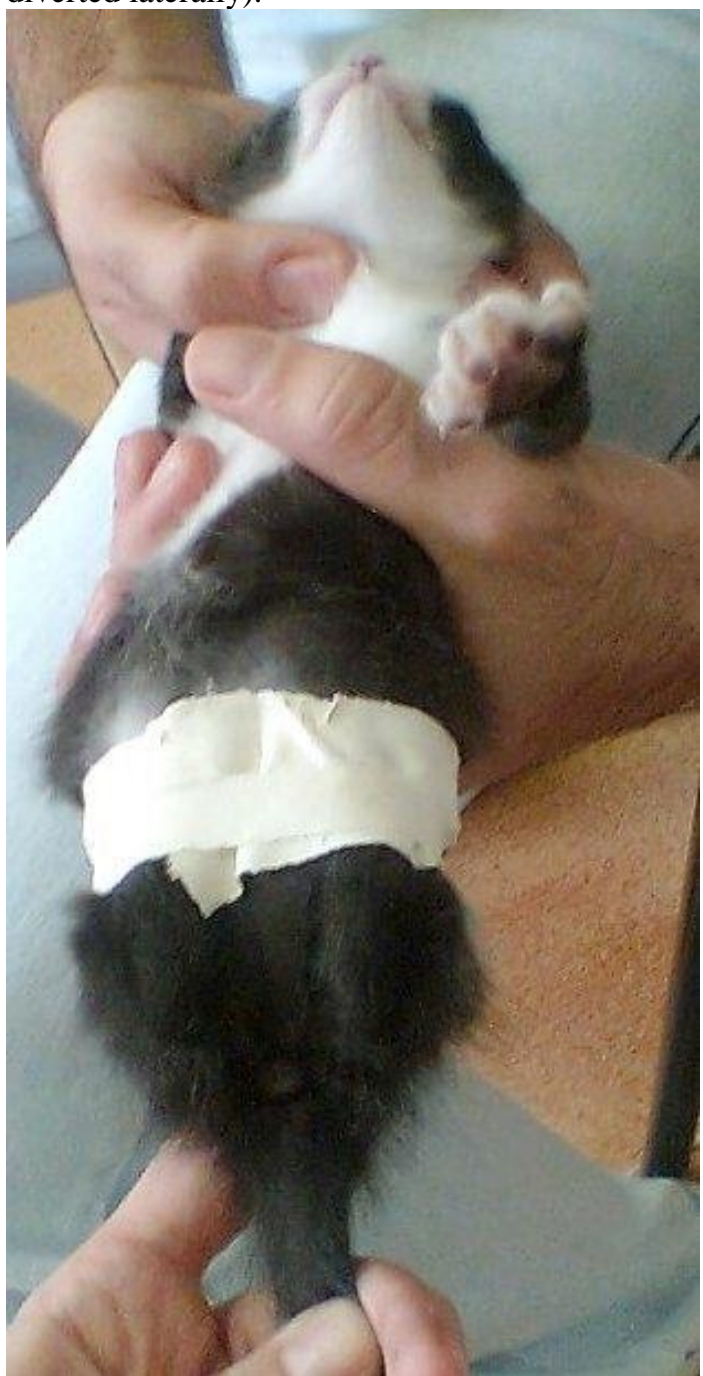

Figure. 2. Practical treatment with tape shackles and bandages on the pelvic limbs, which kept them bent and close to the body.
After seven days of treatment, the kittens were able to adduct both pelvic limbs, and the severe external rotation of the limbs and hyperextension of the tarsal joints had disappeared, and the animals did not exhibit any difficulty to walk, which suggests that the therapy was efficient. The clinical and radiological examination performed after seven days revealed normal functional activity of pelvic and thoracic limbs.

\section{DISCUSSION}

Swimmer syndrome is rare in cats and has been sporadically reported in puppies (Dumon, 2005; Verhoeven et al., 2006; Burger et al., 2007; Fossum, 2007; Yardimci et al., 2009; LindeForsberg, 2010). Verhoeven et al. (2006) and Burger et al. (2007) are among the few authors who have described its clinical aspects and provided some treatment possibilities for cats. Neither study mentioned the involvement of all of the kittens in a litter, which makes the present study an important contribution to the knowledge of clinical and therapeutic aspects of the swimmer syndrome.

All of the newborns lived in the same cattery, over abrasive surface, under satisfactory handling and environmental conditions. Therefore, this disease may be related to excessive protein in maternal nutrition (Dumon, 2005; Verhoeven et al., 2006; Fossum, 2007; Yardimci et al., 2009; Linde-Forsberg, 2010). However, in this report, the queen's diet was balanced and based on good-quality commercial food. A disturbance in maternal metabolism cannot be excluded as a possible cause of this 
syndrome, however, the lactating female was healthy and no clinical signs compatible with metabolic disorder were observed. The hypothesis of a hereditary problem leading to neurological or musculoskeletal development delay is reasonable, because all of the members of the litter were affected.

Swimmer syndrome treatment should include dietary modifications, relocation to rough surface for motor stimulation, anatomical immobilization of the affected limbs, physical therapy, thermo and hydrotherapy, and massage for muscle strengthening (Dumon, 2005; Verhoeven et al., 2006; Burger et al., 2007; Fossum, 2007; LindeForsberg, 2010). The patients received thermotherapy, physical therapy with massage on the quadriceps, biceps femoris muscles, and slight flexion and extension of the pelvic limbs, and tape shackle bandages to fix the lateral displacement and keep the pelvic limbs bent toward the body, providing constant stimulation. Kittens showed faster recovery than puppies, possibly due to weight differences and the growing potential during a small period of time. Therefore, bandages can compromise the growth and expansion of underlying soft tissues in young animals (Verhoeven et al., 2006). Considering these factors, the use of the bandages for only seven days was chosen. No specific treatment was applied for the slight thoracic flattening, since the cause was pressure against sternum secondary to continuousness of the sternal recumbency position, and growth associated with removal of the cause allowed full sternum recovery in two months.

Authors report the use of the same aforementioned therapies applied in puppies and kittens affected with swimmer syndrome, and a significant improvement in the clinical status of the affected animals was observed (Verhoeven $e t$ al., 2006; Burguer et al., 2007; Yardimci et al., 2009). Mills and Levine (1997), Clark and McLaughlin (2001) and Marsolais et al. (2002) recommended hydrotherapy for animals affected by swimmer syndrome, to stimulate muscle activity through swimming exercise, but we decided not to apply this kind of therapy because cats rejected water and could develop pneumonia by inhaling water, due to small body size of kittens with this age.
The success of the therapies implemented in this report can be attributed to early treatment, which was started by the third week of age. According to Hosgood and Hoskins (1998), the affected animals have a favorable prognosis if treated during this period, because bones and articulations are pliable and easy to correct.

The etiopathogenesis of swimmer syndrome remains unclear and this case shows that the disease may have a hereditary etiology, since an entire litter of kittens was affected. With stimulation treatment and muscle strengthening associated with bandages, the animals exhibited a significant improvement after seven days. The kittens were able to ambulate, run, and jump normally. The thoracic slight deformity was not subjected to any specific treatment and has not resulted in clinical problems. The clinical changes associated with swimmer syndrome are amenable to total remission when they are treated early.

\section{ACKNOWLEDGMENTS}

The author is grateful to FUNDUNESP - São Paulo State University (UNESP).

\section{REFERENCES}

BURGER, C.P.; SILVA, R.B.; CANOLA, J.C. et al. Swimmer puppy syndrome: case report. Acta Sci. Vet., v.35, p.1393-1394, 2007.

CLARK, B.; McLAUGHLIN, R.M. Physical rehabilitation in small-animal orthopedic patients. Vet. Med., v.96, p.234-246, 2001.

DUMON, C. The musculoskeletal system: the first 15 days. In: PRATS, A.; GARCIA, F.; DUMON, C. et al. (Ed). Neonatology and pediatrics canine and feline. 1.ed. São Caetano do Sul: Interbook, 2005. p.126-151.

FOSSUM, T.W. Surgery of the lower respiratory system: lungs and thoracic wall. In: FOSSUM, T.W. (Ed). Small Animal Surgery. 3.ed. St. Louis: Mosby, 2007. p.889-892.

FOSSUM, T.W.; BOUDRIEAU, R.J.; HOBSON, H.P. Pectus excavatum in eight dogs and six cats. J. Am. Anim. Hosp. Assoc., v.25, p.595-605, 1985. 
FOSSUM, T.W.; BOUDRIEAU, R.J.; HOBSON, H.P.; RUDY, R.L. Surgical correction of pectus excavatum, using external splintage in two dogs and a cat. J. Am. Vet. Med. Assoc., v.195, p.91-97, 1989.

HOSGOOD, G.; HOSKINS, J.D. Musculoskeletal disorders. In: Small Animal Paediatric Medicine and Surgery. Oxford: Butterworth Heinemann, 1998. p.242-296.

HOSKINS, J.D. Swimmer puppies and kittens. In: HOSKINS, J.D. (Ed). Veterinary Pediatrics. 3.ed. Philadelphia: WB Saunders, 2001. p.419420.

LINDE-FORSBERG, C. Abnormalities in pregnancy, parturition, and the periparturient period. In: ETTINGER, S.J.; FELDMAN, E.C. (Ed). Textbook of Veterinary Internal Medicine. 7.ed. St Louis, Missouri: Elsevier Saunders, 2010. p.1890-1901.

LUDWING, L.L.; SIMPSON, A.M.; HAN, E. Pleural and extrapleural diseases. In: ETTINGER, S.J.; FELDMAN, E.C. (Ed). Textbook of Veterinary Internal Medicine. 7.ed. St Louis: Elsevier Saunders, 2010. v.1, p.11251137.
MARSOLAIS, G.S.; DVORAK, G.; CONZEMIUS, M. Effects of postoperative rehabilitation on limb function after cranial cruciate ligament repair in dogs. J. Am. Vet. Med. Assoc., v.220, p.1325-1330, 2002.

MILLIS, D.L.; LEVINE, D. The role of exercise and physical modalities in the treatment of osteoarthritis. Vet. Clin. N. Am.:Small., v.27, p.913-930, 1997.

RAHAL, S.C.; MORISHIN FILHO, M.M.; HATSCHBACH, E. et al. Pectus excavatum in two littermate dogs. Can. Vet. J., v.49, p.880884, 2008.

RISER, W.H.; FRANKHAUSER, R. Osteopetrosis in the dog: a report of three cases. J. Am. Vet. Radiol. Soc., v.11, p.29-34, 1970.

VERHOEVEN, G.; ROOSTER, H.; RISSELADA, M. et al. Swimmer syndrome in a Devon rex kitten and an English bulldog puppy. J. Small Anim. Pract., v.47, p.615-619, 2006.

YARDIMCI, C.; OZAK, A.; NISBET, H.O. et al. Swimming syndrome in two Labrador puppies. Kafkas Univ. Vet. Fak. Derg., v.15, p.637-640, 2009. 